\title{
Antimutagenicity and induction of antioxidant defense by flavonoid rich extract of Myrcia bella Cambess. in normal and tumor gastric cells
}

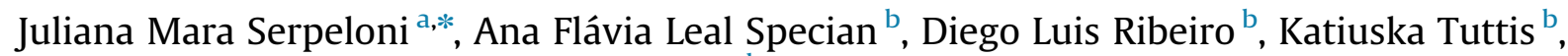 \\ Wagner Vilegas ${ }^{\mathrm{c}}$, Wilner Martínez-López ${ }^{\mathrm{d}}$, Anne Lígia Dokkedal ${ }^{\mathrm{e}}$, \\ Luiz Leonardo Saldanha ${ }^{\mathrm{e}, \mathrm{f}}$, Ilce Mara de Syllos Cólus ${ }^{\mathrm{b}}$, Eliana Aparecida Varanda ${ }^{\mathrm{a}}$ \\ a Department of Biological Sciences, Faculty of Pharmaceutical Sciences, São Paulo State University (UNESP), Araraquara 14801-902, Brazil \\ ${ }^{\mathrm{b}}$ Department of General Biology, Center of Biological Sciences, State University of Londrina (UEL), Londrina 86057-970, Brazil \\ ${ }^{\mathrm{c}}$ Experimental Campus of São Vicente, São Paulo State University (UNESP), São Vicente 11350-000, Brazil \\ d Instituto de Investigaciones Biológicas Clemente Estable, Montevideo 11600, Uruguay \\ e Department of Biological Sciences, Faculty of Sciences, São Paulo State University (UNESP), Bauru 17033-360, Brazil \\ ${ }^{\mathrm{f}}$ Department of Botany, Institute of Bioscience, São Paulo State University (UNESP), Botucatu 18618-970, Brazil
}

\section{A R T I C L E I N F O}

\section{Article history:}

Received 2 June 2015

Received in revised form

14 October 2015

Accepted 1 November 2015

Available online 6 November 2015

Keywords:

Antioxidant

Antiproliferative

Gastric disorders

Myrcia bella

Mutagenicity

Necrosis

Chemical compounds studied in this article: Azure A (PubChem CID: 13735)

Acridine orange (PubChem CID: 62344)

Bromophenol blue (PubChem CID: 8272)

Cytochalasin B (PubChem CID: 5311281)

Dimethyl sulfoxide (PubChem CID: 679)

Doxorubicin (PubChem CID: 31703)

Ethidium bromide (PubChem CID: 14710)

Hydrogen peroxide (PubChem CID: 784)

Propidium iodide (PubChem CID: 104981)

Thiazolyl blue (PubChem CID: 64965)

\begin{abstract}
A B S T R A C T
Ethnopharmacological relevance: The Brazilian "Cerrado" is an important source of natural products, such as Myrcia bella Cambess (MB, also known as "mercurinho"). MB leaves are popularly used for the treatment of diabetes and gastrointestinal disorders; however, only its hypoglycemic activity has been experimentally described.

Aim of the study: Because MB is used to treat gastrointestinal disorders, the present study characterized biological activities of hydroalcoholic MB extract in human normal and tumor gastric cells.

Materials and methods: Cytotoxic, antiproliferative, genotoxic and protective effects were evaluated, as well as the effects of the MB extract on gene expression.

Results: The MB extract induced cytotoxicity in tumor cells at lower concentrations compared with normal cells as assessed by the MTT assay. Moreover, the MB extract induced necrosis based on acridine orange/ethidium bromide staining. An antiproliferative effect was evidenced through an arrest in the G2/ $\mathrm{M}$ phase detected by flow cytometry and a decrease in the nuclear division index using the cytokinesisblock micronucleus cytome assay. Cells treated with MB extract combined with doxorubicin (DXR) showed increased NUBDs, which may be related to the gene amplification of CCND1. Antimutagenic effects were also observed and may be associated with the antioxidant activities detected using the CM- $\mathrm{H}_{2}$ DCFDA probe.

Conclusions: Our findings showed the following: (a) high concentrations of MB induced cytotoxicity and cell death by necrosis; (b) its antiproliferative effect was associated with G2/M arrest; and (c) its antioxidant activity could be responsible for the observed antimutagenic effects and for protective effects against gastrointestinal disorders previously described to MB. Although these effects are not specific to normal or tumor cells, they provide a panel of biological activities for further exploration.
\end{abstract}

(c) 2015 Elsevier Ireland Ltd. All rights reserved.

\section{Introduction}

Currently, enormous efforts are focused on the analysis of plant extracts for use for medical purposes (Hammad et al., 2014). The Myrcia genus, which includes approximately 350 species, belongs to the subfamily Myrtoidea, Myrtaceae (Landrum and Kawasaki, 1997). Species of this genus are used in folk medicine in Brazil as

\footnotetext{
* Correspondence to: Departamento de Biologia Geral, Rodovia Celso Garcia Cid, PR 445, km 380, s/n, CEP: 86057-970 Londrina, Paraná, Brazil.

E-mail address: julianaserpeloni@yahoo.com.br (J.M. Serpeloni).
}

astringents, diuretics, and coagulants, and for the treatment of diseases such as diabetes mellitus, hypertension and gastric ulcers (Hashimoto, 1996; Pepato et al., 1993; Russo et al., 1989). Myrcia spp. are typically found in the Brazilian savannah (the "Cerrado"), which is home to a large number of endemic species (Myers et al., 2000), including Myrcia bella Cambess. (MB).

The leaves of MB (also known as "mercurinho") (Pott et al., 2006) has been used in Brazilian folk medicine for different purposes and are also exploited commercially as herbal drugs for the treatment of diabetes mellitus (Saldanha et al., 2013). A recent paper confirmed that extracts from MB leaves had hypoglycemic properties and possibly regulated glucose uptake by the liver 
(Vareda et al., 2014). However, this is the only scientific report concerning the biological and toxicological properties of this species. In contrast, several studies investigated the biological properties of Myrcia spp. Salvador et al. (2011) evaluated the antioxidant capacity of ethanolic extracts of four different species of the Myrtaceae family (two each belonging to the genus Myrcia: Myrcia laruotteana Cambess and Myrcia obtecta (Berg) Kiacrsk). The authors demonstrated that the M. laruotteana and $M$. obtecta extracts had higher antioxidant activity compared to the flavonoid quercetin using the radical sequestration 2,2-diphenyl-1-picrylhydrazyl (DPPH) test. The floroacetophene 2',4',6'-trihydroxyacetophenone (THA), an acetophenone isolated from Myrcia multiflora, also showed antioxidant activity in vitro and in vivo (Ferreira et al., 2010). Moreover, THA and other compounds isolated from $M$. multiflora demonstrated some pharmacological properties, such as hypolipidemic and anti-obesity activities (Ferreira et al., 2011). Ferreira et al. (2006) suggested that the chronic consumption of $M$. uniflora could induce hypothyroidism, especially in individuals who ingested small quantities of iodine and patients with thyroid dysfunction, because the compounds in the aqueous fraction of the methanol extract decreased the synthesis of thyroid hormones by reducing thyroid peroxidase activity.

The pharmacological activities related to the Myrcia spp. also included antidiabetic activity. For example, diabetic rats treated with an aqueous extract of $M$. uniflora showed improvement in metabolic parameters related to glucose homeostasis (Pepato et al., 1993). Rats treated with myrciacitrins extracted from $M$. multiflora leaves showed a decrease in the activity of the enzyme aldose reductase; this enzyme catalyzes the reduction of glucose to sorbitol, representing the first step in glucose metabolism (Matsuda et al., 2002).

Considering that Brazilian people have used plants of Myrcia genus against disorders of the gastrointestinal tract (Hashimoto, 1996) and that only hypoglycemic activity was described to MB we performed a panel of toxicological tests to characterize the possible in vitro cytotoxic, antiproliferative, oxidant/antioxidant and mutagenic activities of the hydroalcoholic extract of MB leaves in normal and tumor (ACP02) human gastric cells. We also evaluated the protective effects of the extract against damage induced by the chemotherapeutic doxorubicin (DXR).

\section{Material and methods}

\subsection{Plant material}

Samples of MB leaves from natural origins were collected at the Botanical Garden of Bauru-SP, Brazil $\left(22^{\circ} 20^{\prime} 30^{\prime \prime} \mathrm{S}\right.$ and $49^{\circ} 00^{\prime} 30^{\prime \prime}$ W) in November, 2010. The plant name was verified with http:// www.theplantlist.org. Voucher specimens were identified using macroscopic and microscopic methods by Prof. Dr. Anne L. Dokkedal and stored at the Herbarium of the São Paulo State University UNBA (UNESP, SP, Brazil) under code number 5508. The standardized hydroalcoholic extract (EtOH 70\%) used in the present study was produced via percolation and chemically characterized by HPLC-PDA-MS based analysis as described by Saldanha et al. (2013).

\subsection{Cell culture conditions}

Tumor (ACP02) and normal human primary cells obtained by biopsy were provided by Prof. Dr. Rommel Burbano (Federal University of Pará, UFPA, Brazil) (Leal et al., 2009). Cells between the 3rd and 8th passage were defrosted and cultivated in Dulbecco's Modified Eagle's Medium (DMEM) high glucose plus 10\% fetal bovine serum (FBS) (Gibco, Grand Island, NY, USA) and 1.0\% penicillin and streptomycin (Sigma-Aldrich, St-Louis, $\mathrm{MO}$, USA) in a $5 \% \mathrm{CO}_{2}$ atmosphere at $37{ }^{\circ} \mathrm{C}$ and $96 \%$ relative humidity. Three independent cultures were used to evaluate all parameters. The treatment medium was serum-free except for the assessment of the cell proliferation curves (Repetto et al., 2008). Positive (DXR $0.200 \mu \mathrm{g} / \mathrm{mL}$, Sigma-Aldrich, St. Louis, MO, USA) and negative control groups (phosphate buffered saline-PBS) were included in the assays.

\subsection{MTT assays}

MTT assays were conducted as described by Mosmann (1983) using 3-[4,5-Dimethylthiazol-2-yl]-2,5-diphenyl tetrazolium bromide (CAS: 298-93-1, Sigma-Aldrich, St. Louis, MO, USA). Briefly, $1.0 \times 10^{4}$ cells were seeded per well in a 96-well plate and exposed to MB extract $(5.00-500 \mu \mathrm{g} / \mathrm{mL})$ or DXR $(0.05-2.50 \mu \mathrm{g} / \mathrm{mL})$ for $24 \mathrm{~h}$. The highest concentration of MB extract and DXR tested was based on their maximum dilution in PBS.

After $24 \mathrm{~h}$ of incubation, the cells were treated with MTT $(0.50 \mathrm{mg} / \mathrm{mL})$ and incubated for $4 \mathrm{~h}$; then, $200 \mu \mathrm{L}$ of DMSO were added to each well. Absorbances at $570 \mathrm{~nm}$ were measured on microplate spectrophotometers (Biotek Eon, Winooski, VT, USA). The results were expressed as the percentage of viable cells in relation to the negative control group (PBS).

\subsection{Cell proliferation curves}

According to Seibert et al. (1996), cytotoxicity should be determined by using cell proliferation endpoint in which the time of exposure to treatment should be at least three time as long as the doubling time of the cells employed. For this reason, besides MTT assay we also employed cell proliferations curves where cells were treated for 5 days.

A total of $2.5 \times 10^{4}$ cells were seeded into a 24-well plate and exposed to two non-cytotoxic $(5.00$ and $100 \mu \mathrm{g} / \mathrm{mL})$ and one cytotoxic $(200 \mu \mathrm{g} / \mathrm{mL})$ concentration of MB extract chosen from the MTT assay. The cells were harvested after 24, 48, 72, 96 and $120 \mathrm{~h}$ of treatment and $20 \mu \mathrm{L}$ of the cell suspension was used for cell counting in a Neubauer chamber. Cell proliferation was evaluated by the total protein content using the method described by da Costa Lopes et al. (2000) and standardized in our laboratory (Ciliao et al., 2015). Results of MTT assay and cell proliferations curves were used to choose non-cytotoxic concentrations to be tested in next protocols.

\subsection{Cytokinesis-block micronucleus cytome assay (CBMN-cyt)}

DNA instability was evaluated using CBMN-cyt according to the method of Fenech (2007). Briefly, $1.0 \times 10^{6}$ cells were stabilized in $25 \mathrm{~cm}^{3}$ culture flasks (Corning, Lowell, MA, USA) to test non-cytotoxic concentrations of MB extract $(5.00,50.0$ or $100 \mu \mathrm{g} / \mathrm{mL})$ and the controls. To evaluate the protective effects of the MB extract on DXR-induced DNA damage, the cells were treated with DXR associated to the MB extract $(100 \mu \mathrm{g} / \mathrm{mL})$ in protocols of pre-treatment (PRE), simultaneous (SIM) and post-treatment (POST). In PRE, cells were treated with MB for $24 \mathrm{~h}$ followed by $24 \mathrm{~h}$ of treatment with DXR. In POST, DXR was administrated before the extract for the same time totalizing $48 \mathrm{~h}$ of treatment. In SIM, DXR and $\mathrm{MB}$ extract were administered together during $24 \mathrm{~h}$.

After treatments, the cultures were exposed to $3 \mu \mathrm{g} / \mathrm{mL}$ cyt-B (CAS: 14930-96-2, Sigma-Aldrich, St. Louis, MO, USA) for $30 \mathrm{~h}$. The cells were harvested as described by Fenech (2007) using $1.0 \%$ sodium citrate as the hypotonic solution. After fixation, slides were prepared and stained with 5.0\% Giemsa (CAS: 1.09204.0500, Merck $^{\circledR}$, Rio de Janeiro, RJ, Brazil) diluted in phosphate buffer (0.06 $\mathrm{M} \mathrm{Na}_{2} \mathrm{HPO}_{4}$ and $0.06 \mathrm{M} \mathrm{KH}_{2} \mathrm{PO}_{4}, \mathrm{pH}$ 6.8) for $10 \mathrm{~min}$, then 
Table 1

List of primers sequences used for RT-qPCR.

\begin{tabular}{|c|c|c|}
\hline Gene & Sequence $5^{\prime}-3^{\prime}$ & $\begin{array}{l}\text { Size of the amplification pro- } \\
\text { duct (base pairs) }\end{array}$ \\
\hline MET & $\begin{array}{l}\text { F: TACGGTCCTATGGCTGGT } \\
\text { R: CTCTCGGTTGGCTAAGTC }\end{array}$ & 201 \\
\hline CCND1 & $\begin{array}{l}\text { F: CATTGAACACTTCСТСТССА } \\
\text { R: AАСTTCACATCTGTGGCAC }\end{array}$ & 140 \\
\hline BIRC5 & $\begin{array}{l}\text { F: GACTTGTGTGTGATGAGAG } \\
\text { R: TAGAATGGCTTTGTGCTTAG }\end{array}$ & 138 \\
\hline$B A X$ & $\begin{array}{l}\text { F: TTTCTGACGGCAACTTCAACTGGG } \\
\text { R: TGTCCAGCCCATGATGGTTCTGAT }\end{array}$ & 121 \\
\hline$B C L-X L$ & $\begin{array}{l}\text { F: CAGCCGAGAGCCGAAAGG } \\
\text { R: GAGGGTAGAGTGGATGGTC }\end{array}$ & 132 \\
\hline TP53 & $\begin{array}{l}\text { F: CCATCCACTACAACTACAT } \\
\text { R: GCACAAACACGCACCTC }\end{array}$ & 136 \\
\hline HPRT1 & $\begin{array}{l}\text { F: TCCTCTGCTCCGCCACCG } \\
\text { R: TCATCACTAATCACGACGCC }\end{array}$ & 101 \\
\hline GAPDH & $\begin{array}{l}\text { F: GGGCATCCTGGGCTACACT } \\
\text { R: GGTCCAGGGGTCTTACTC }\end{array}$ & 208 \\
\hline
\end{tabular}

analyzed under a light microscopic (Nikon Eclipse E200, Tokyo, Japan) with 400x magnification. To score micronuclei (MNis), the frequencies of nucleoplasmatic bridges (NPBs) and nuclear buds (NBUDs), 3000 binucleated cells were analyzed per experimental point. A total of 1500 viable cells was scored to calculate the nuclear division index (NDI) using the formula described by Fenech (2007).

\subsection{DNA content by flow cytometry analysis}

Experimental protocols similar to those described above for CBMN-cyt were used for flow cytometry analysis with the inclusion of a cytotoxic MB concentration $(200 \mu \mathrm{g} / \mathrm{mL})$. Cells were trypsinized and centrifuged at $70 \times g$ for $5.0 \mathrm{~min}$; then, the cell pellets were washed with PBS and centrifuged for an additional $5.0 \mathrm{~min}$. The supernatant was removed and the pellet was resuspended in $2.0 \mathrm{~mL}$ of ice-cold ethanol (70\% in water; $\mathrm{v} / \mathrm{v}$ ). At the time of analysis, the cells were centrifuged; then, the ethanol was removed and the cells were resuspended in $1.0 \mathrm{~mL}$ of PBS. The cells were centrifuged one more time, the supernatants were discarded and the cells were incubated in $200 \mu \mathrm{L}$ of propidium iodide (PI) solution (10 mL PBS, $10 \mu \mathrm{L}$ Triton, $100 \mu \mathrm{L}$ RNAse, and $40 \mu \mathrm{L}$ of $1 \mathrm{mg} / \mathrm{mL} \mathrm{PI}$ ) for $30 \mathrm{~min}$. After incubation, the samples were subjected to a fluorescence activated cell sorter (Becton Dickinson, Franklin Lake, NJ, USA). The data were analyzed using the Cell Quest software, and the cell cycle profiles were determined using the Flow Jo software (Tree Star Incorporation, Ashland, OR, USA).

\subsection{Apoptosis/necrosis assays}

The protocol described by McGahon et al. (1995) was applied to distinguish between viable, apoptotic and necrotic cells to enable the investigation into the mechanism involved in cell death. In total, $1.0 \times 10^{5}$ cells were seeded into 12 -well plates and treated for 1.0, 3.0, 6.0, 12 and $24 \mathrm{~h}$ with MB extract (5.00, 100, 200 and $400 \mu \mathrm{g} / \mathrm{mL}$ ) and the controls. The cells were trypsinized, and $25 \mu \mathrm{L}$ of the suspension was mixed with $1.0 \mu \mathrm{L}$ of staining solution containing $100 \mu \mathrm{g} / \mathrm{mL}$ acridine orange (AO) and $100 \mu \mathrm{g} / \mathrm{mL}$ ethidium bromide (EB). A total of 600 cells was analyzed with a Nikon fluorescence microscope (Tokyo, Japan) using an excitation wavelength of $515-560 \mathrm{~nm}$ and a $590 \mathrm{~nm}$ barrier filter. The results were presented as the percentages of viable, apoptotic and necrotic cells.

\subsection{Oxidant/antioxidant assay}

Intracellular reactive species (RS) were measured using 5-(and6)-chloromethyl-2',7'-dichlorodihydrofluorescein diacetate, acetyl ester ( $\mathrm{CM}-\mathrm{H}_{2}$ DCFDA, Life technologies, Eugene, OR, USA). Cells were seeded into sterile black plates and exposed to $5.00,100$ or $200 \mu \mathrm{g} / \mathrm{mL}$ of MB extract for $1.0,3.0,6.0,12$ and $24 \mathrm{~h}$ with their respective controls. After treatments, the wells were washed with PBS; then, $100 \mu \mathrm{L}$ of a $5 \mathrm{mM} \mathrm{CM}-\mathrm{H}_{2}$ DCFDA solution was added and incubated for $30 \mathrm{~min}$ at $37^{\circ} \mathrm{C}$. Thereafter, $1 \mathrm{mM}$ hydrogen peroxide $\left(\mathrm{H}_{2} \mathrm{O}_{2}\right)$ was added for $15 \mathrm{~min}$ to the positive control group and simultaneous treatment group, followed by a wash with PBS. Finally, $100 \mu \mathrm{L}$ of PBS were added to each well, and the absorbances were read on a Victor ${ }^{\mathrm{TM}} \mathrm{X} 3$ multilabel plate reader (PerkinElmer, São Paulo, Brazil) at excitation $k=485 \mathrm{~nm}$ and emission $k=528 \mathrm{~nm}$. The results were presented as the fluorescence intensity.

\subsection{Quantitative real-time polymerase chain-reaction (RT-qPCR)}

The treatment protocols were the same as those employed in the CBMN-cyt assay using $5.00,100$ or $200 \mu \mathrm{g} / \mathrm{mL}$ of $\mathrm{MB}$ extract alone or $100 \mu \mathrm{g} / \mathrm{mL}$ MB extract in combination with DXR.

Total RNA was extracted from the cells using the PureLink ${ }^{\circledR}$

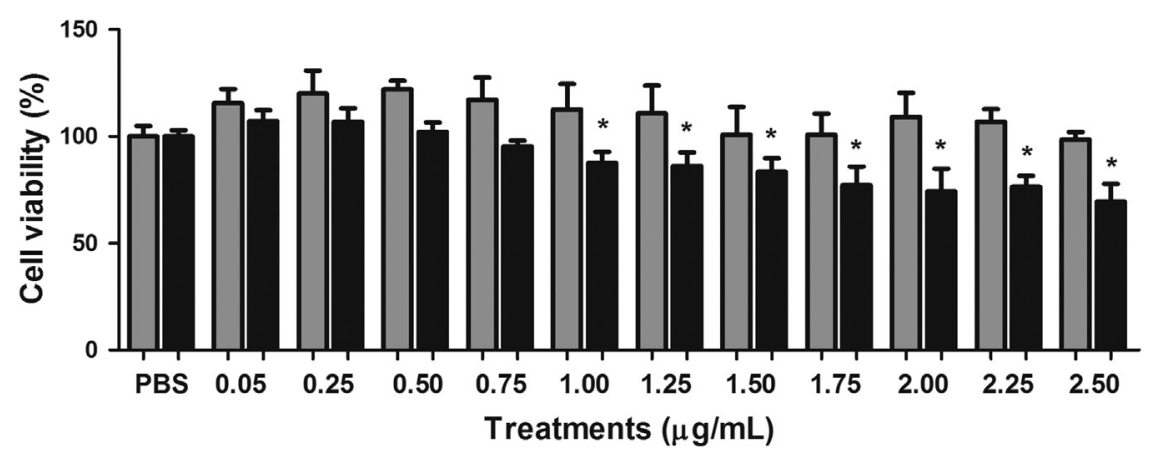

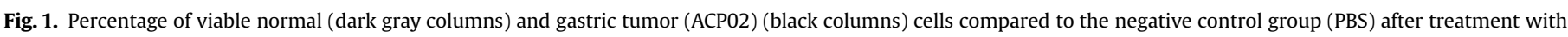

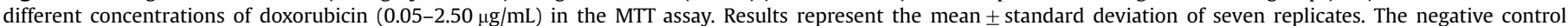
represents $100 \%$ of viability. PBS: phosphate buffered saline. *Significantly different from the negative control, ANOVA followed by Tukey's test ( $p \leq 0.05$ ). 


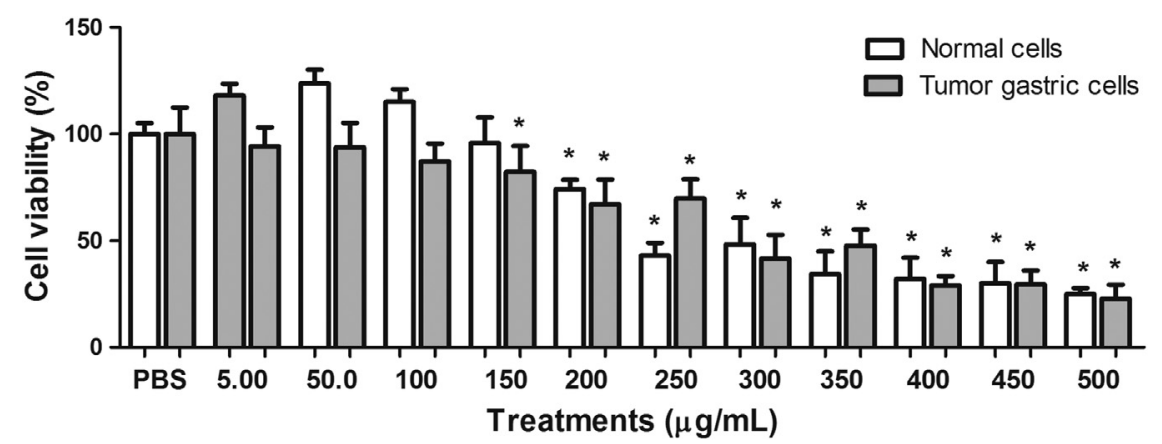

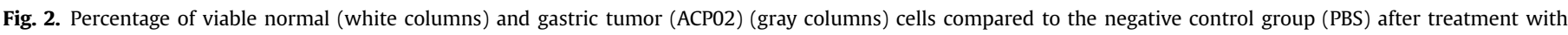

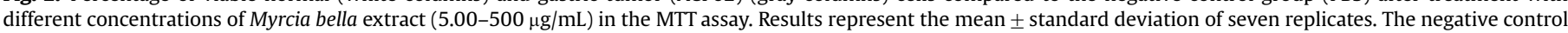
represents $100 \%$ of viability. PBS: phosphate buffered saline. *Significantly different from the negative control, ANOVA followed by Tukey's test ( $p \leq 0.05$ ).

RNA Mini Kit (Life Technologies, Carlsbad, CA, USA). The quantity of RNA was determined by spectrophotometry (NanoDrop 2000CThermo Scientific, San Jose, CA, USA). RNA quality and integrity were assessed by electrophoresis in an agarose gel (Aranda et al., 2012). RNA samples were treated with DNase I (Amplification Grade, Invitrogen, Carlsbad, CA, USA) following the recommendations of the manufacturer.

The RNA was reverse-transcribed using the SuperScript III First Strand Synthesis System, Oligo-DT ${ }^{12-18}$ and random primers from Invitrogen (Carlsbad, CA, USA) following manufacturer's protocol.

Reference genes were selected using the normalization program NormFinder. Primers for GAPDH (glyceraldehyde-3-phosphate dehydrogenase) and HPRT1 (hypoxanthine guanine phosphoribosyl transferase 1) as well as the genes of interest TP53 (tumor protein p53), CCND1 (cyclin D1), BAX (B-cell lymphoma 2-associated $\mathrm{X}$ protein), $B C L-X L$ (B-cell lymphoma-extra-large),
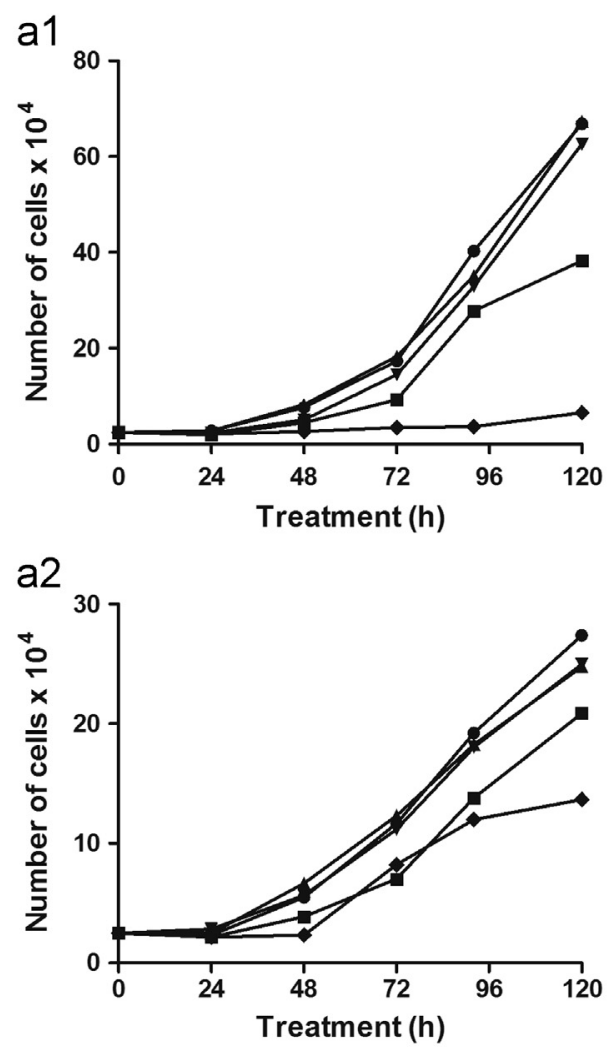

BIRC5 (Baculoviral inhibitor of apoptosis repeat containing 5) and MET (hepatocyte growth factor receptor) were generated using Gene Runner Software Version 3.05 (Spruyt and Buquicchio, 1994). Primer sequences are listed in Table 1. The primers for the CAT (catalase), GSR (glutathione reductase), GPx1 (glutathione peroxidase 1) and NFE2L2 (nuclear factor, erythroid 2-like 2) genes were obtained from the KiCqStart ${ }^{\circledR}$ SYBR Green Primers (Sigma-Aldrich). The efficiency was determined by testing serial dilutions of cDNA until the best annealing temperature was obtained.

PCR runs were performed using the Techne Quantum ${ }^{\text {TM }}$ Real Time PCR Cycler System (Staffordshire, UK) with the Platinum ${ }^{\circledR}$ SYBR $^{\circledR}$ Green qPCR SuperMix UGD (Invitrogen, Carlsbad, CA, USA). The final volume was $10 \mu \mathrm{L}$ and contained $20 \mathrm{pmol}$ of each primer and $10 \mathrm{ng}$ of the cDNA template. The reaction mixture was subjected to the following amplification program: $95^{\circ} \mathrm{C}$ for $5 \mathrm{~min}$, followed by 50 cycles of $95^{\circ} \mathrm{C}$ for $15 \mathrm{~s}, 60{ }^{\circ} \mathrm{C}$ for $15 \mathrm{~s}$ and $72{ }^{\circ} \mathrm{C}$ for

b1

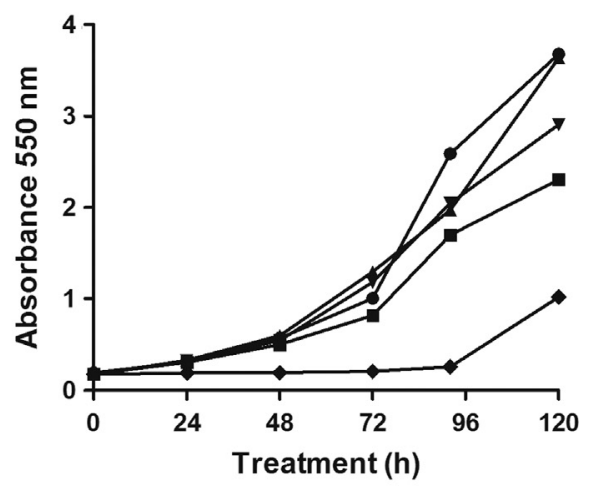

b2

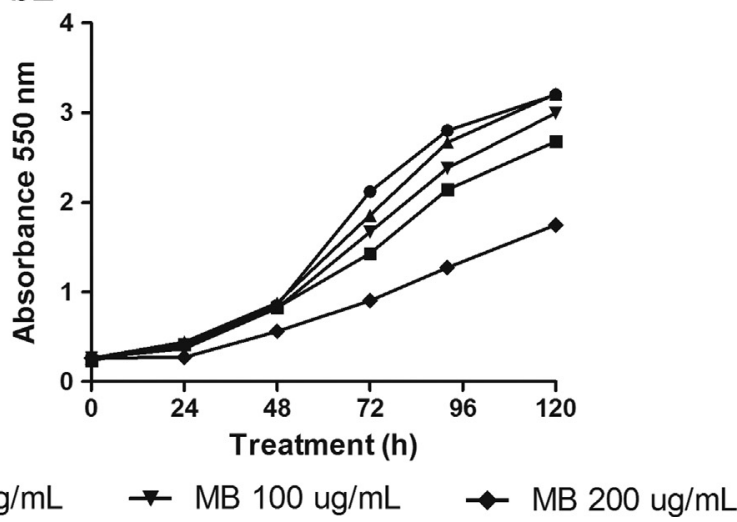

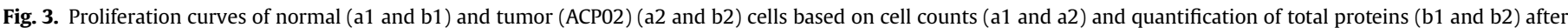
treatment with Myrcia bella extract (MB) compared to the negative (PBS) and positive control (DXR) groups. PBS: phosphate buffered saline; DXR: doxorubicin. 
Table 2

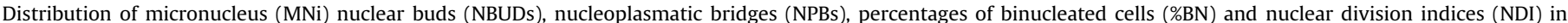

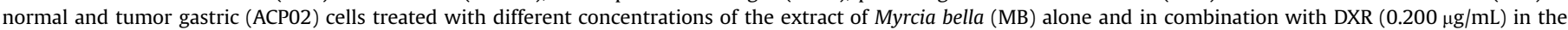

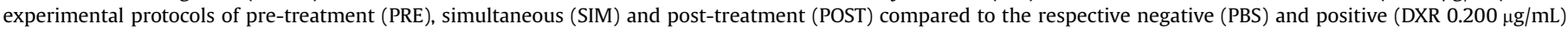
control groups.

\begin{tabular}{|c|c|c|c|c|c|c|c|c|c|c|}
\hline \multirow{3}{*}{ TREATMENTS } & \multicolumn{10}{|c|}{ Parameters analyzed in CBMN-cyt } \\
\hline & \multicolumn{2}{|l|}{ MN } & \multicolumn{2}{|l|}{ NUBDs } & \multicolumn{2}{|l|}{ NPBs } & \multicolumn{2}{|l|}{ \%BN } & \multicolumn{2}{|l|}{ NDI } \\
\hline & GAS & ACP02 & GAS & ACP02 & GAS & ACP02 & GAS & ACP02 & GAS & ACP02 \\
\hline \multicolumn{11}{|l|}{ Mutagenicity } \\
\hline PBS & $8.0 \pm 1.00$ & $8.7 \pm 2.52$ & $1.3 \pm 0.6$ & $2.0 \pm 1.00$ & $1.7 \pm 1.5$ & $6.3 \pm 0.58$ & $67.9 \pm 0.92$ & $81.3 \pm 3.23$ & $1.89 \pm 0.02$ & $2.02 \pm 0.02$ \\
\hline DXR & $29.3 \pm 2.52 *$ & $30.3 \pm 3.21^{*}$ & $5.7 \pm 2.5^{*}$ & $5.7 \pm 1.53$ & $5.0 \pm 2.7^{*}$ & $6.7 \pm 1.15$ & $52.9 \pm 1.63^{*}$ & $66.1 \pm 2.00^{*}$ & $1.57 \pm 0.02^{*}$ & $1.83 \pm 0.01 *$ \\
\hline MB 5.00 & $8.0 \pm 3.61$ & $6.3 \pm 2.52$ & $2.7 \pm 1.2$ & $5.7 \pm 1.53$ & $3.3 \pm 1.7$ & $6.0 \pm 2.65$ & $64.6 \pm 1.40$ & $75.7 \pm 0.50$ & $1.84 \pm 0.03$ & $2.00 \pm 0.02$ \\
\hline MB $\mathbf{5 0 . 0}$ & $13.3 \pm 3.06$ & $5.3 \pm 1.53$ & $2.7 \pm 1.2$ & $5.0 \pm 1.73$ & $1.7 \pm 0.6$ & $5.3 \pm 2.52$ & $55.8 \pm 2.55$ & $74.4 \pm 2.97$ & $1.66 \pm 0.05^{*}$ & $1.78 \pm 0.03 *$ \\
\hline MB 100 & - & $7.3 \pm 1.53$ & - & $9.0 \pm 1.73^{*}$ & - & $3.0 \pm 0.00$ & $23.9 \pm 3.79^{*}$ & $47.0 \pm 3.94^{*}$ & $1.25 \pm 0.03^{*}$ & $1.48 \pm 0.04^{*}$ \\
\hline \multicolumn{11}{|c|}{ Antimutagenicity } \\
\hline$\overline{\text { PBS }}$ & $2.0 \pm 1.00$ & $7.7 \pm 2.08$ & $0.7 \pm 0.58$ & $2.7 \pm 2.08$ & $0.3 \pm 0.58$ & $2.0 \pm 0.01$ & $80.7 \pm 1.36$ & $72.9 \pm 2.72$ & $1.94 \pm 0.07$ & $1.96 \pm 0.03$ \\
\hline DXR & $25.3 \pm 1.53^{*}$ & $41.0 \pm 2.83^{*}$ & $3.7 \pm 1.53^{*}$ & $9.5 \pm 3.54^{*}$ & $4.7 \pm 1.53^{*}$ & $12.0 \pm 0.03^{*}$ & $55.4 \pm 3.90^{*}$ & $51.3 \pm 6.93^{*}$ & $1.61 \pm 0.04^{*}$ & $1.72 \pm 0.04^{*}$ \\
\hline MB + DXR & - & - & - & - & - & - & $7.4 \pm 0.72$ & $15.8 \pm 1.44^{* \#}$ & $1.08 \pm 0.03^{* \#}$ & $1.18 \pm 0.06$ *\# \\
\hline \multicolumn{11}{|l|}{ SIM } \\
\hline$\overline{\text { PBS }}$ & $2.7 \pm 0.58$ & $8.0 \pm 2.65$ & $1.0 \pm 1.00$ & $4.7 \pm 2.52$ & $1.7 \pm 0.58$ & $5.3 \pm 1.15$ & $75.5 \pm 1.60$ & $74.87 \pm 1.47$ & $1.88 \pm 0.03$ & $1.94 \pm 0.01$ \\
\hline DXR & $24.3 \pm \mathbf{0 . 5 8}^{*}$ & $39.7 \pm 5.51^{*}$ & $1.3 \pm 1.53$ & $5.0 \pm 2.6$ & $6.0 \pm 1.00$ & $14.7 \pm 2.52^{*}$ & $68.5 \pm 2.32 *$ & $66.07 \pm 2.60^{*}$ & $1.72 \pm 0.03^{*}$ & $1.83 \pm 0.02^{*}$ \\
\hline MB + DXR & $11.7 \pm 3.51^{* \#}$ & $23.3 \pm 3.51$ *\# & $4.3 \pm 1.15^{*}$ & $17.0 \pm 1.73^{* \#}$ & $2.0 \pm 1.00$ & $8.3 \pm 4.04$ & $64.8 \pm 1.64^{*}$ & $66.07 \pm 2.08$ & $1.71 \pm \mathbf{0 . 0 2} *$ & $1.72 \pm 0.03^{* \#}$ \\
\hline \multicolumn{11}{|l|}{ POST } \\
\hline$\overline{\text { PBS }}$ & $2.0 \pm 1.00$ & $7.7 \pm 2.08$ & $1.0 \pm 0.00$ & $2.7 \pm 2.08$ & $0.7 \pm 0.58$ & $2.0 \pm 0.01$ & $75.6 \pm 0.69$ & $72.93 \pm 2.72$ & $1.80 \pm 0.02$ & $1.96 \pm 0.03$ \\
\hline DXR & $23.3 \pm 2.52$ & $34.7 \pm 2.08 *$ & $3.6 \pm 2.08$ & $11.0 \pm 4.36^{*}$ & $2.3 \pm 0.58$ & $10.0 \pm 2.20$ & $66.9 \pm 2.40^{*}$ & $66.47 \pm 0.31^{*}$ & $1.80 \pm 0.04$ & $1.85 \pm 0.04^{*}$ \\
\hline MB + DXR & $19.0 \pm 2.65^{*}$ & $32.5 \pm 3.54^{*}$ & $3.0 \pm 2.65$ & $11.5 \pm 0.71^{*}$ & $2.0 \pm 1.73$ & $13.5 \pm 4.95^{*}$ & $33.6 \pm 2.00$ & $53.30 \pm 0.71$ *\# & $1.36 \pm 0.01 * \#$ & $1.60 \pm 0.01$ *\# \\
\hline
\end{tabular}

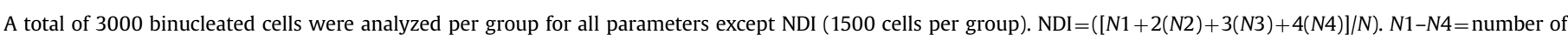

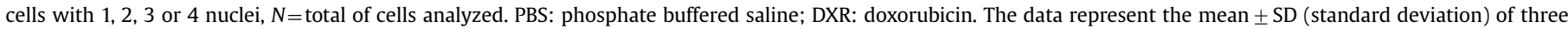
independent experiments.

${ }^{\#}$ Significantly different from the positive control group $(p \leq 0.05)$. ANOVA and Tukey's test.

* Significantly different from the negative control group $(p \leq 0.05)$.

15 s. Finally, a melting curve was generated in the range of 50 $95^{\circ} \mathrm{C}$.

Gene expression data were analyzed with the Quantsoft V.1.1.30 cycle threshold $(\mathrm{Ct})$ for each sample in the linear region of the amplification plot. GAPDH and HPRT1 genes were selected to normalize target gene expression. Relative quantification of gene expression was calculated according to Pfaffl (2001).

\subsection{Statistical analysis}

One-way analysis of variance (ANOVA) followed by Tukey's test was performed with the GraphPad Prism $5^{\circledR}$ software system (La Jolla, CA, USA). All data are presented as mean \pm standard deviation with $p \leq 0.05$.

Changes in gene expression were compared to the control situation and considered to be significantly different when $p \leq 0.05$.

\section{Results}

\subsection{MTT assay}

The results obtained from the MTT assay after treatment of the cells with DXR and the MB extract are presented in Figs. 1 and 2, respectively. Only tumor gastric cells exhibited decreased cell viability after treatment with DXR (Fig. 1) at concentrations equal or higher than $1.00 \mu \mathrm{g} / \mathrm{mL}$. Fig. 2 shows that no cytotoxic effects were seen when normal (white columns) and ACP02 tumor cells (gray columns) were exposed to the MB extract in doses up
$200 \mu \mathrm{g} / \mathrm{mL}$ and up to $150 \mu \mathrm{g} / \mathrm{mL}$, respectively. These results indicated that concentrations of $0.200 \mu \mathrm{g} / \mathrm{mL}$ for DXR and doses up to $150 \mu \mathrm{g} / \mathrm{mL}$ for the $\mathrm{MB}$ extract were non-cytotoxic; these concentrations were applied in the following assays.

\subsection{Cell proliferation curves}

Cell proliferation curves were performed to assess the cytotoxic and non-cytotoxic concentrations of the MB extract obtained from the MTT assay (Fig. 3). Exposure to the cytotoxic concentration of the MB extract $(200 \mu \mathrm{g} / \mathrm{mL})$ reduced cell growth, as demonstrated by the curves of cell counts (3a) and protein content (3b) for normal (3a1, 3b1) and ACP02 (3a2, 3b2) cells. Moreover, the noncytotoxic DXR concentration $(0.200 \mu \mathrm{g} / \mathrm{mL})$ was not cytotoxic after $24 \mathrm{~h}$ of treatment, which confirmed the MTT assay results. However, this concentration reduced cell proliferation in both cell types after $48 \mathrm{~h}$ of treatment.

\subsection{CBMN cyt}

The results obtained from the analysis of MNi, NPBs and NBUDs in binucleated cells that reflect the possible mutagenic and antimutagenic activity of the MB extract are presented in Table 2 . The MN induction factor (IF) in cells treated with MB extract was similar to the negative control group, while the IF was 3.67 in cells treated with DXR. Only the highest concentration of MB extract $(100 \mu \mathrm{g} / \mathrm{mL})$ changed the frequency of NBUDs in tumor cells (Table 2). Neither MNi nor NPBs was altered in either cell line after treatment with different concentrations of the MB extract.

The highest concentration $(100 \mu \mathrm{g} / \mathrm{mL})$ decreased the NDI in 

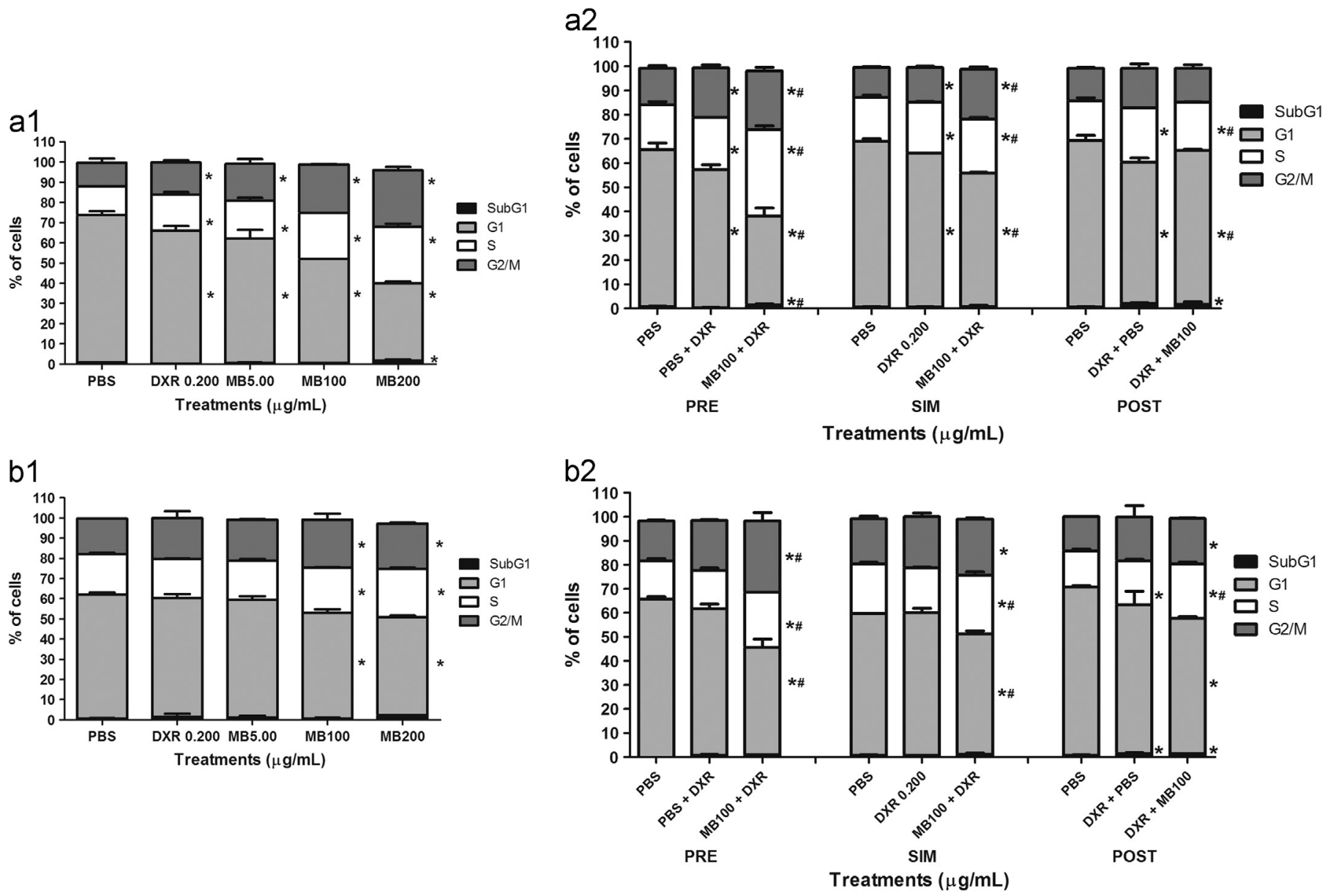

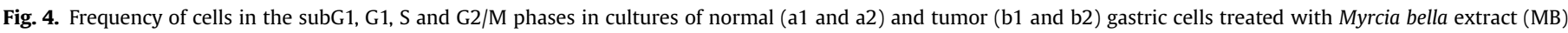

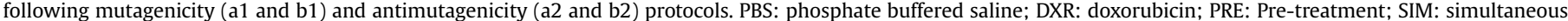

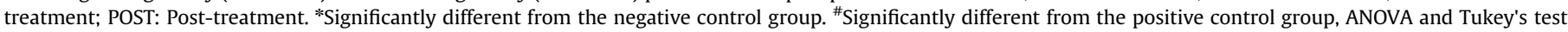
$(p \leq 0.05)$.

both cell types relative to the control group. This decrease was more evident in normal cells, with $100 \mu \mathrm{g} / \mathrm{mL}$ of MB extract inducing a strong antiproliferative effect that made it impossible to analyze the CBMN-cyt parameters.

The MB extract concentration of $100 \mu \mathrm{g} / \mathrm{mL}$ was chosen to evaluate the antimutagenicity, because this concentration did not show mutagenic effects. In both cell types, the association of MB extract with DXR in the PRE protocol decreased cell proliferation to levels that made the scoring of MNi, NPBs and NBUDs impossible. Interestingly, this phenomenon was not observed when the SIM and POST experimental protocols were used (Table 2). Moreover, protective effects were observed only when the cells were exposed simultaneously to MB extract and DXR in both cell lines. MB extract reduced DNA damage by $54 \%$ and $52 \%$ in the normal and tumor cells lines, respectively.

\subsection{DNA content analysis by flow cytometry}

The antiproliferative effects of the MB extract may be the result of changes in the cell cycle. Thus, the effect of MB on the cell cycle was assessed for both cell lines. The results of the flow cytometry analysis after treatment with different concentrations of MB extract $(5.00,100$ and $200 \mu \mathrm{g} / \mathrm{mL})$ are shown in Fig. 4; Fig. 4a1 and a2 shows data obtained with normal cells and Fig. 4b1 and b2 shows data obtained with tumor cells. Only the highest concentration of MB extract was cytotoxic in normal gastric cells, as evidenced by the increase in the SubG1 cell population. DXR and all extract concentrations induced an arrest in the G2/M and $\mathrm{S}$ phases of tumor cells. This result was observed only for the 100 and $200 \mu \mathrm{g} / \mathrm{mL}$ extract concentrations in normal cells.

Similar to the results observed in the CBMN-cyt assay, pretreatment of the cells induced a strong arrest in the G2/M and $S$ phases.

\subsection{Apoptosis/necrosis assay}

Next, we investigated the mechanisms involved in the cytotoxic effects of the MB extract. Results observed after 1.0, 3.0, 6.0, 12 and $24 \mathrm{~h}$ of treatment of normal and tumor cells are presented in Table 3. In general, concentrations that had previously demonstrated cytotoxic effects in the MTT and cell proliferation curves (200 and $400 \mu \mathrm{g} / \mathrm{mL}$ ) induced cell death by necrosis in both cell types, even after only one hour of treatment. Moreover, this necrotic effect increased following longer treatment times, with the highest concentration of the $\mathrm{MB}$ extract $(400 \mu \mathrm{g} / \mathrm{mL})$ resulting in the death of all normal gastric cells after $3 \mathrm{~h}$ of treatment. This strong cytotoxic effect made impossible the counting of cells.

DXR induced cell death only in tumor cells by apoptosis after 3.0 or $6.0 \mathrm{~h}$ of treatment and by necrosis after $24 \mathrm{~h}$.

\subsection{Oxidant/antioxidant evaluation}

The quantification of reactive species in normal and tumor cells is shown in Fig. 5a and b, respectively. The absorbance obtained 
Table 3

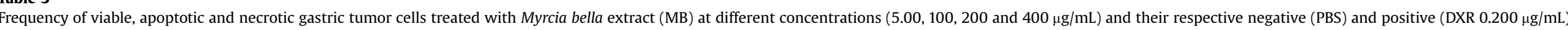
controls.

\begin{tabular}{|c|c|c|c|c|c|c|c|c|c|c|c|c|c|}
\hline \multirow[b]{3}{*}{ Time of Treatment } & \multicolumn{13}{|c|}{ Treatments $(\mu \mathrm{g} / \mathrm{mL})$} \\
\hline & & \multicolumn{2}{|l|}{ PBS } & \multicolumn{2}{|l|}{ DXR 0.2} & \multicolumn{2}{|l|}{ MB5 } & \multicolumn{2}{|l|}{ MB100 } & \multicolumn{2}{|l|}{ MB200 } & \multicolumn{2}{|l|}{ MB400 } \\
\hline & & GAS & ACP02 & GAS & ACP02 & GAS & ACP02 & GAS & ACP02 & GAS & ACP02 & GAS & ACP02 \\
\hline $1 \mathrm{~h}$ & $\begin{array}{l}\text { V } \\
\text { A } \\
\mathrm{N}\end{array}$ & $\begin{array}{l}95.5 \pm 1.41 \\
1.50 \pm 0.00 \\
3.00 \pm 1.41\end{array}$ & $\begin{array}{l}89.50 \pm 3.54 \\
5.00 \pm 2.83 \\
5.50 \pm 0.71\end{array}$ & $\begin{array}{l}95.00 \pm 1.41 \\
2.75 \pm 2.12 \\
2.25 \pm 0.70\end{array}$ & $\begin{array}{l}87.00 \pm 0.00 \\
8.50 \pm 3.54 \\
4.50 \pm 3.54\end{array}$ & $\begin{array}{l}97.00 \pm 0.00 \\
1.75 \pm 0.71 \\
1.25 \pm 0.71\end{array}$ & $\begin{array}{l}91.50 \pm 0.71 \\
6.00 \pm 1.41 \\
2.50 \pm 0.71\end{array}$ & $\begin{array}{l}85.00 \pm 4.24 \\
1.50 \pm 1.41 \\
13.50 \pm 5.66\end{array}$ & $\begin{array}{l}91.00 \pm 1.41 \\
6.50 \pm 2.12 \\
2.50 \pm 0.71\end{array}$ & $\begin{array}{l}\mathbf{8 5 . 0 0} \pm \mathbf{4 . 2 4} \\
1.50 \pm 1.41 \\
\mathbf{1 3 . 5 0} \pm \mathbf{5 . 6 6}\end{array}$ & $\begin{array}{l}\mathbf{7 5 . 5 0} \pm \mathbf{2 . 1 2} \\
2.50 \pm 0.71 \\
\mathbf{2 2 . 0 0} \pm \mathbf{1 . 4 1}^{*}\end{array}$ & $\begin{array}{l}\mathbf{2 7 . 0 0} \pm \mathbf{2 . 8 3} \\
2.00 \pm 0.00 \\
\mathbf{7 1 . 0 0} \pm \mathbf{2 . 8 3}\end{array}$ & $\begin{array}{l}\mathbf{7 8 . 5 0} \pm \mathbf{4 . 2 4} \\
3.50 \pm 2.12 \\
\mathbf{1 8 . 0 0} \pm \mathbf{1 . 4 1}\end{array}$ \\
\hline $3 \mathrm{~h}$ & $\begin{array}{l}\text { V } \\
\text { A } \\
N\end{array}$ & $\begin{array}{l}94.75 \pm 2.12 \\
1.50 \pm 0.00 \\
3.75 \pm 2.12\end{array}$ & $\begin{array}{l}92.00 \pm 4.24 \\
6.00 \pm 1.41 \\
2.00 \pm 2.83\end{array}$ & $\begin{array}{l}96.00 \pm 1.41 \\
1.75 \pm 0.71 \\
2.25 \pm 0.71\end{array}$ & $\begin{array}{l}86.50 \pm 0.71 \\
\mathbf{1 1 . 0 0} \pm \mathbf{0 . 0 0} \\
2.50 \pm 0.71\end{array}$ & $\begin{array}{l}96.25 \pm 2.12 \\
1.00 \pm 0.00 \\
2.75 \pm 2.12\end{array}$ & $\begin{array}{l}93.5 \pm 2.12 \\
5.50 \pm 2.12 \\
1.00 \pm 0.00\end{array}$ & $\begin{array}{l}92.25 \pm 2.12 \\
1.25 \pm 0.71 \\
6.50 \pm 1.41\end{array}$ & $\begin{array}{l}93.50 \pm 0.71 \\
5.00 \pm 0.00 \\
1.50 \pm 0.71\end{array}$ & $\begin{array}{l}86.00 \pm 4.24 \\
1.00 \pm 0.00 \\
13.00 \pm 4.24\end{array}$ & $\begin{array}{l}89.50 \pm 0.71 \\
1.00 \pm 0.00 \\
9.50 \pm 1.71\end{array}$ & $\begin{array}{l}\text { NA } \\
\text { NA } \\
\text { NA }\end{array}$ & $\begin{array}{l}\mathbf{7 0 . 5 0} \pm \mathbf{4 . 9 5} \\
3.50 \pm 3.54 \\
\mathbf{2 6 . 0 0} \pm \mathbf{8 . 4 9}\end{array}$ \\
\hline $6 \mathrm{~h}$ & $\begin{array}{l}\text { V } \\
\text { A } \\
N\end{array}$ & $\begin{array}{l}95.50 \pm 1.41 \\
1.00 \pm 0.00 \\
3.50 \pm 1.41\end{array}$ & $\begin{array}{l}90.00 \pm 9.90 \\
5.50 \pm 0.71 \\
4.50 \pm 0.00\end{array}$ & $\begin{array}{l}91.50 \pm 0.00 \\
4.75 \pm 2.12 \\
3.75 \pm 2.12\end{array}$ & $\begin{array}{c}92.00 \pm 1.41 \\
\mathbf{6 . 0 0} \pm \mathbf{1 . 4 1} \\
2.00 \pm 0.00\end{array}$ & $\begin{array}{l}96.25 \pm 4.95 \\
2.00 \pm 4.24 \\
1.75 \pm 0.71\end{array}$ & $\begin{array}{l}96.00 \pm 1.41 \\
2.50 \pm 0.71 \\
1.50 \pm 0.71\end{array}$ & $\begin{array}{l}90.0 \pm 1.41 \\
1.00 \pm 0.00 \\
9.00 \pm 1.41\end{array}$ & $\begin{array}{l}90.50 \pm 0.71 \\
2.00 \pm 0.00 \\
7.50 \pm 0.71\end{array}$ & $\begin{array}{l}85.25 \pm 12.02 \\
1.25 \pm 0.71 \\
13.50 \pm 11.31\end{array}$ & $\begin{array}{l}\mathbf{7 7 . 0 0} \pm \mathbf{2 . 8 3} \\
3.50 \pm 0.71 \\
\mathbf{1 9 . 5 0} \pm \mathbf{2 . 1 2}\end{array}$ & $\begin{array}{l}\text { NA } \\
\text { NA } \\
\text { NA }\end{array}$ & $\begin{array}{l}\mathbf{5 1 . 0 0} \pm \mathbf{1 . 4 1} \\
3.00 \pm 2.83 \\
\mathbf{4 6 . 0 0} \pm \mathbf{1 . 4 1}\end{array}$ \\
\hline $12 \mathrm{~h}$ & $\begin{array}{l}\text { V } \\
\text { A } \\
\mathrm{N}\end{array}$ & $\begin{array}{l}96.75 \pm 0.71 \\
1.00 \pm 0.00 \\
2.25 \pm 0.71\end{array}$ & $\begin{array}{l}90.50 \pm 0.71 \\
7.50 \pm 0.71 \\
2.00 \pm 0.00\end{array}$ & $\begin{array}{l}92.75 \pm 0.71 \\
5.25 \pm 0.71 \\
2.00 \pm 0.00\end{array}$ & $\begin{array}{l}87.00 \pm 2.83 \\
8.00 \pm 1.41 \\
5.00 \pm 1.41\end{array}$ & $\begin{array}{l}96.25 \pm 0.71 \\
1.75 \pm 2.12 \\
2.00 \pm 1.41\end{array}$ & $\begin{array}{l}91.00 \pm 1.41 \\
6.00 \pm 1.41 \\
3.00 \pm 0.00\end{array}$ & $\begin{array}{l}89.00 \pm 8.49 \\
1.25 \pm 0.71 \\
9.75 \pm 7.78\end{array}$ & $\begin{array}{l}90.00 \pm 1.41 \\
2.50 \pm 0.71 \\
7.50 \pm 0.71\end{array}$ & $\begin{array}{l}61.50 \pm 14.14 \\
0.75 \pm 0.71 \\
37.75 \pm 13.44\end{array}$ & $\begin{array}{l}85.50 \pm 0.71 \\
3.00 \pm 0.00 \\
11.50 \pm 0.71\end{array}$ & $\begin{array}{l}\text { NA } \\
\text { NA } \\
\text { NA }\end{array}$ & $\begin{array}{l}\mathbf{7 8 . 0 0} \pm \mathbf{5 . 6 6} \\
1.50 \pm 0.71 \\
\mathbf{2 0 . 5 0} \pm \mathbf{0 . 7 1}\end{array}$ \\
\hline $24 \mathrm{~h}$ & $\begin{array}{l}\text { V } \\
\text { A } \\
\text { N }\end{array}$ & $\begin{array}{l}94.75 \pm 0.71 \\
2.00 \pm 0.00 \\
3.25 \pm 0.71\end{array}$ & $\begin{array}{l}93.50 \pm 0.71 \\
6.00 \pm 0.00 \\
0.50 \pm 0.71\end{array}$ & $\begin{array}{l}86.00 \pm 5.66 \\
8.75 \pm 0.71 \\
5.25 \pm 4.95\end{array}$ & $\begin{array}{l}\mathbf{8 8 . 5 0} \pm \mathbf{0 . 7 1} \\
6.50 \pm 1.41 \\
\mathbf{5 . 0 0} \pm \mathbf{0 . 0 0}\end{array}$ & $\begin{array}{l}95.50 \pm 1.41 \\
2.00 \pm 0.00 \\
2.50 \pm 1.41\end{array}$ & $\begin{array}{l}92.50 \pm 2.12 \\
4.50 \pm 0.71 \\
3.00 \pm 1.41\end{array}$ & $\begin{array}{l}87.50 \pm 7.07 \\
1.75 \pm 2.12 \\
10.75 \pm 4.95\end{array}$ & $\begin{array}{l}91.00 \pm 1.41 \\
1.50 \pm 2.12 \\
\mathbf{7 . 5 0} \pm \mathbf{0 . 7 1}\end{array}$ & $\begin{array}{l}61.50 \pm 4.24 \\
1.00 \pm 0.00 \\
37.50 \pm 11.31\end{array}$ & $\begin{array}{l}\mathbf{7 3 . 5 0} \pm \mathbf{0 . 7 1} \\
2.50 \pm 0.71 \\
\mathbf{2 4 . 0 0} \pm \mathbf{1 . 4 1}\end{array}$ & $\begin{array}{l}\text { NA } \\
\text { NA } \\
\text { NA }\end{array}$ & $\begin{array}{l}\mathbf{5 3 . 5 0} \pm \mathbf{2 . 1 2} \\
0.50 \pm 0.71 \\
\mathbf{4 6 . 0 0} \pm \mathbf{2 . 8 3}\end{array}$ \\
\hline
\end{tabular}

Cells were sampled at 1.0, 3.0, 6.0, 12 and $24 \mathrm{~h}$ after treatment. PBS: phosphate buffered saline. DXR: doxorubicin. NA: not analyzed (treatments where it was impossible to count the cells due to high cytotoxicity).

* Significantly different from the negative control group (PBS), ANOVA and Tukey's test ( $p \leq 0.05)$. 
a
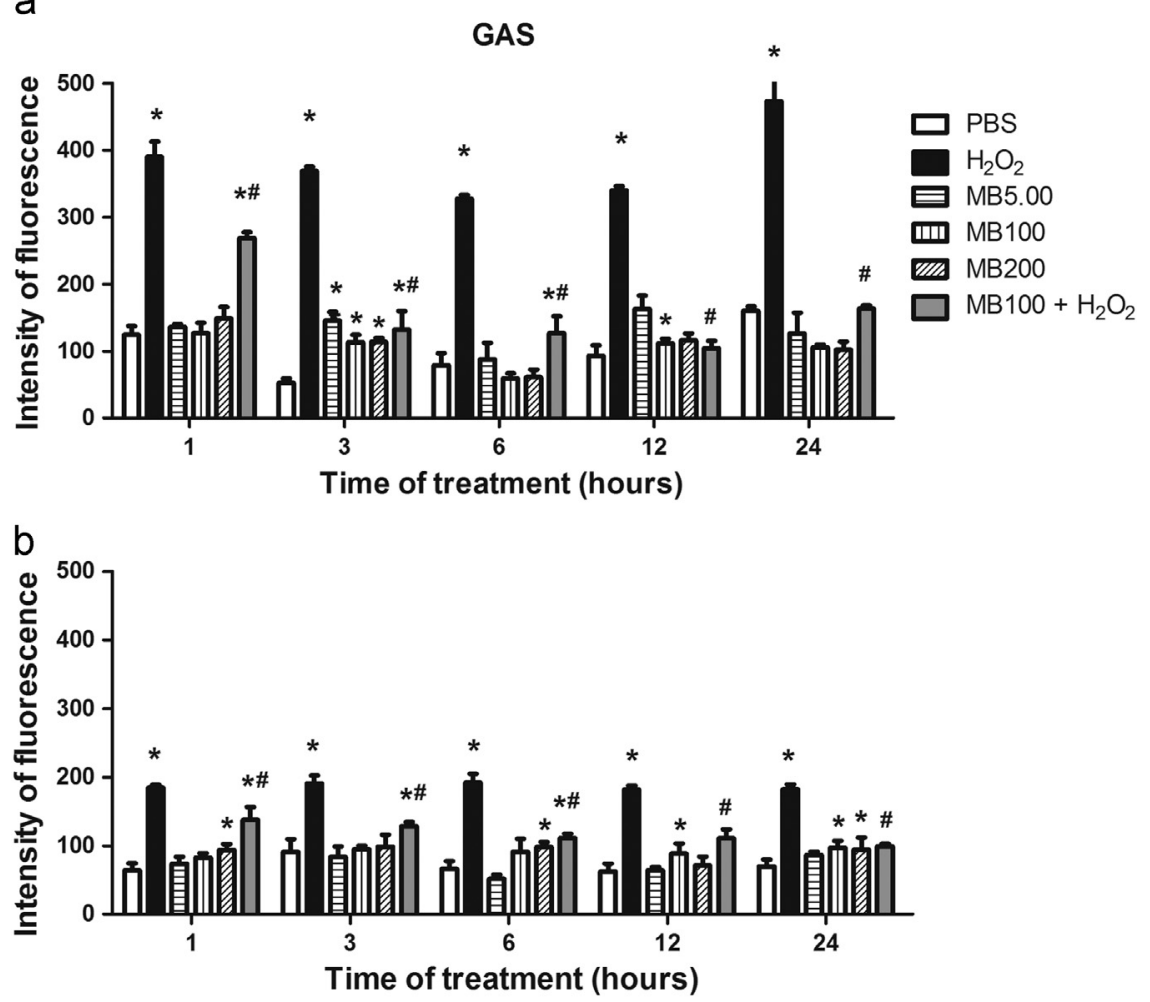

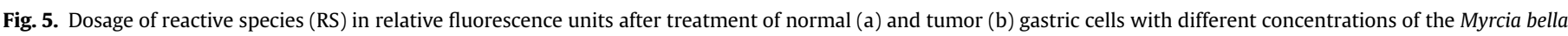

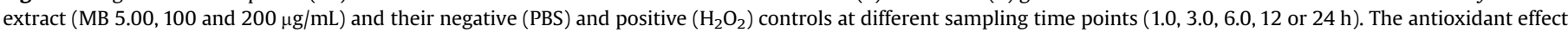

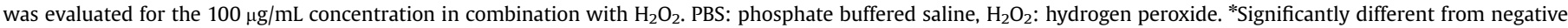
control $(p \leq 0.05)$. "Significantly different from the positive control group $(p \leq 0.05)$, ANOVA and Tukey's test.

after treatment with different $\mathrm{MB}$ extract concentrations were compared to cells treated with PBS to evaluate the oxidant activity and to cells treated with $\mathrm{PBS}+\mathrm{H}_{2} \mathrm{O}_{2}$ to evaluate antioxidant activity. None of the concentrations of MB extract tested showed an oxidant effect in normal cells. However, in tumor cells, the $200 \mu \mathrm{g} / \mathrm{mL}$ concentration induced an oxidant effect at all-time points, while the $100 \mu \mathrm{g} / \mathrm{mL}$ concentration showed an oxidant effect at 12 and $24 \mathrm{~h}$.

Antioxidant effects were observed in both cell types at every treatment time point. However, the reduction in the intensity of fluorescence was more evident in the normal compared to the tumor cells.

\subsection{Gene expression analysis}

Finally, we analyzed gene expression using RT-qPCR (Fig. 6) in normal (Fig. 6a1) and tumor gastric cells (Fig. 6b1 and b2).

The expression levels of the genes TP53, BAX, BCL-XL, BIRC5, $M E T, C A T, G S R$ and GPx1 were not modulated by DXR or MB extract alone or in combination. The expression of the proto-oncogene CCND1 increased in the combined treatment protocols (MB + DXR) in both cell types. Furthermore, the expression of NFE2L2 decreased in tumor cells treated with the cytotoxic concentration of the extract (MB $200 \mu \mathrm{g} / \mathrm{mL}$ ).

\section{Discussion}

Plant extracts remain an important source of studies related to the prevention and treatment of diseases. Promising results in the evaluation of crude plant extracts directed the search towards the active components responsible for their biological and pharmacological activities. In some cases, the interaction among bioactive compounds in the extract is responsible for its biological activity (Hammad et al., 2014). Thus, it is logical to investigate crude extracts in the search for biological activities prior to testing their bioactive compounds individually.

Some bioactive components from plants showed anticancer activities (Wang et al., 2012). Crude vegetal extracts have also been investigated concerning their anticancer properties (Jeong et al., 2015; Tai et al., 2014; Xu et al., 2013). The biological activities of the Myrcia bella extract were investigated even though promising results were found for another species of this genus.

In the present study, we evaluated possible cytotoxic effects by assessing the effect of a range of extract concentrations in normal and tumor cells (ACP02). Tumor cells were more sensitive than normal cells. Thus, it is important to select concentrations that kill tumor cells, but do not induce disturbances in the homeostasis of healthy cells. The AO/BE test demonstrated that cytotoxic concentrations (200 and $400 \mu \mathrm{g} / \mathrm{mL}$ ) killed both type of cell lines (normal and tumor) by inducing the necrosis process instead of apoptosis.

The MTT assay detects alterations in mitochondrial integrity and its capacity to exert its cellular functions (Bernhard et al., 2003); however, this test did not detect changes in cell proliferation. For these reason, we generated cell proliferation curves. Importantly, in contrast to the cytotoxic effects that were detected only in tumor cells at the concentration of $200 \mu \mathrm{g} / \mathrm{mL}$ after $24 \mathrm{~h}$ of treatment in the MTT assay, the same concentration exhibited an antiproliferative capacity in both cell types when longer time periods were analyzed using the cell proliferation curves. This antiproliferative effect was studied in more detail in the NDI evaluation 
a1

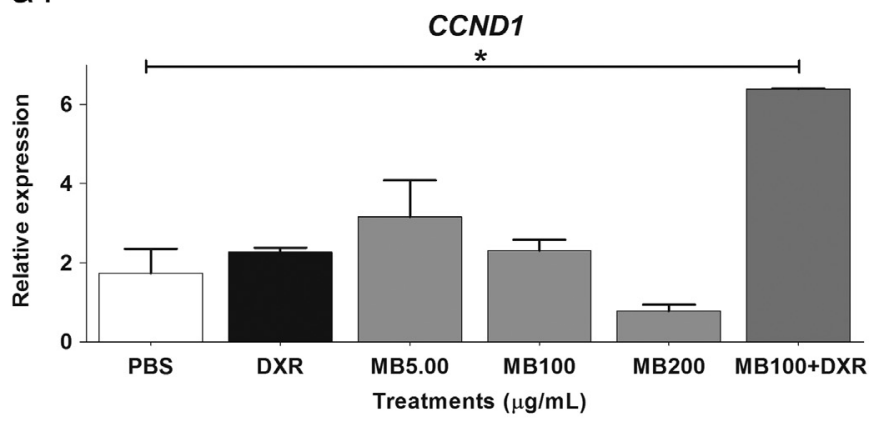

b1

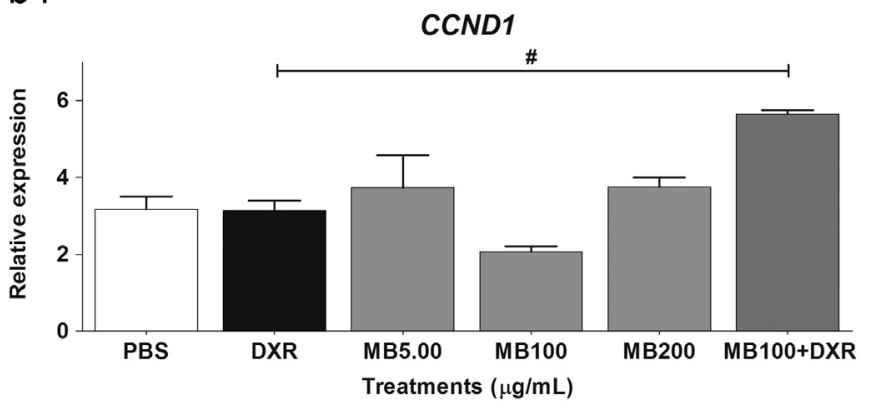

b2

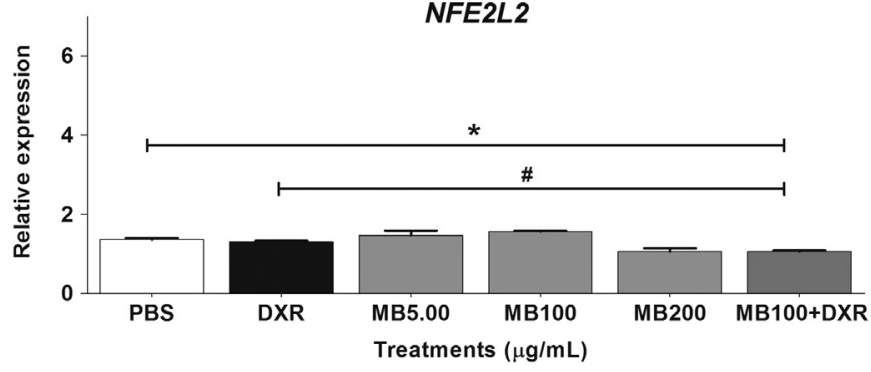

Fig. 6. Relative expression of selected genes in normal (a) and tumor (b1; b2; b3) gastric cells after treatment with different concentrations of Myrcia bella extract (MB) alone or in combination with DXR. The results are presented as relative expression of the selected genes in different conditions. Bars indicate the standard deviation of the replicates. PBS: phosphate buffered saline. DXR: doxorubicin. *Significantly different from the negative control (PBS). "Significantly different from the positive control (DXR), Student's $t$ test ( $p \leq 0.05$ ).

and flow cytometry. All of these tests showed an antiproliferative effect of the extract, even at the lowest concentrations tested (50.0 and $100 \mu \mathrm{g} / \mathrm{mL}$ ). This effect became more evident when the MB extract was associated with the chemotherapeutic DXR, another antiproliferative agent.

Aside from this antiproliferative effect, mutagenic activity was not observed in either cell line based solely on the frequency of micronucleated cells. One exception that should be noted is that the frequency of NUBDs in tumor cells was almost five-fold higher than the negative control group. This result highlights the importance of evaluating different parameters in the CBMN-cyt assay, as proposed by Fenech (2006). The NUBD and NPB frequencies are poorly evaluated in most studies, which may lead to negative results concerning mutagenicity similar to our observations in the present study. Our results suggested that the MB extract possessed mutagenic activity based on the increase in NUBDs. Evaluation of the oxidant activity using the $\mathrm{CM}-\mathrm{H}_{2}$ DCFA probe showed an oxidant effect of the MB extract only on tumor cells, which may be related to the mutagenic effect observed in these cells. Chua et al. (2014) also demonstrated that the frequency of NUBDs increased with the oxidative stress induced by $\mathrm{H}_{2} \mathrm{O}_{2}$ in an astrocytoma cell line.
Antimutagenic effects were observed in both cell lines in the CBMN-cyt assays when the cells were treated with the MB extract plus DXR. This antimutagenic property associated with the recently described hypoglycemic activity (Vareda et al., 2014) encourages the search for beneficial activities of the MB extract at concentrations that do not induce cytotoxic effects. Based on the NDI results, the PRE treatments involving combination of the MB extract and DXR had a strong antiproliferative effect. This effect was so strong in normal cells that the analysis of the CBMN-cyt parameters was not possible. In agreement with this finding, the cell cycle analysis showed an increase in the Sub-G1 population in this same treatment group, but only in normal cells.

Antimutagens include compounds that have different mechanisms of action, including antioxidant activity (Sloczynska et al., 2014). The results obtained using the $\mathrm{CM}-\mathrm{H}_{2}$ DCFDA probe suggest that the antimutagenic activity could be related to the observed antioxidant effect. Because the $\mathrm{MB}$ extract was administered prior to the induction of reactive species by $\mathrm{H}_{2} \mathrm{O}_{2}$, some compounds in the extract could have removed these species before they reacted with the DNA and induced DNA damage (Lee et al., 2011). A direct antioxidant effect of MB was supported by the RT-qPCR results that showed that cells did not present alterations in the expression patterns of antioxidant genes. A reduction in NFE2L2 expression was observed in tumor cells when the MB extract was combined with DXR; this result indicated that this DNA protection pathway was not impaired in normal cells. Several studies have correlated gastrointestinal diseases with inflammation and increased oxidative stress (Ock et al., 2012; Suzuki et al., 2012). Suzuki et al. (2012) noted that the use of antioxidants was important to increase the antioxidant and anti-inflammatory capacity and prevent the onset of gastrointestinal disorders. Given our results, the antioxidant activity of the MB extract could be linked to the traditional use of MB against diseases of the gastrointestinal tract.

The present study demonstrated that the NUBD frequency after treatment with the MB extract in combination with DXR in a simultaneous experimental protocol in normal and tumor cells was higher compared to the control cells. One mechanism involved in NUBDs formation is gene amplification (Fenech et al., 2011) and/or removal of DNA repair complexes (Chua et al., 2014). Our results cannot identify which gene is amplified, but one hypothesis is that the overexpression of different genes may be related to increases in the NUBDs frequency, including CCND1 that had its expression increased approximately five-fold in both cell lines. We also propose that the increased CCND1 expression could represent a strategy used by the cells to repair the damage induced by DXR; in support of these findings, Jirawatnotai et al. (2012) previously revised the role of the CCND1 protein in the process of DNA repair.

It is possible to try to explain the observed effects based on the chemical composition of the MB extract. HPLC-PDA-MS based analysis (data not shown) confirms the presence of flavonoids and phenolic acids derivatives in MB extract used in this study. In a recent paper from our research group (Saldanha et al., 2013) regarding the chemical composition of $\mathrm{MB}$, we showed that its main constituents were flavonoid aglycones, flavonoid-O-glycosides, and acylated flavonoid-O-glycoside derivatives of quercetin and myricetin. Depending on the concentration tested, these compounds may exhibit cytotoxic and pro-oxidant activities (Heeba and Mahmoud, 2014; Zhang et al., 2009). Other interesting results observed with the MB extract are the antimutagenic and antioxidant properties that were also demonstrated for quercetin and myricetin (Barcelos et al., 2011; Chen et al., 2011; Hayder et al., 2008; Mladenovic et al., 2013).

The antiproliferative capacity was the most obvious biological effect observed in this work; strategies involving the inhibition of cell cycle progression have been extensively evaluated in order to 
manage the progression of tumors (Schwartz and Shah, 2005). Zhang et al. (2009) demonstrated that quercetin and myricetin were able to induce cell cycle arrest in the G2/M phase in another gastrointestinal tract cell line (the esophageal squamous cell carcinoma cell line KYSE-510). Several studies demonstrated the capacity of quercetin (Berndt et al., 2013; Choi et al., 2001; Li et al., 2014) and myricetin (Sun et al., 2012; Wang et al., 2004; Zhang et al., 2011) to induce G2/M arrest in different cell types. Haddad et al. (2006) demonstrated that different flavonoids exerted their antiproliferative effects at lower doses in prostate cancer cells compared to normal prostate cells. We observed an inverse effect in the present work, because even the lowest concentrations of the MB extract evaluated induced G2/M arrest in normal cells but not in tumor cells.

In summary, the mutagenic effect observed through the increase in NUBDs formation in tumor cells may be related to the oxidative stress observed in these cells and the gene amplification of the CCND1 gene. Moreover, the cell cycle arrest in the G2/M phase could be related to the observed antiproliferative results. The antioxidant effects demonstrated using the $\mathrm{CM}-\mathrm{H}_{2} \mathrm{DCFDA}$ probe were most likely responsible for the antimutagenic effects observed in both cell types. Importantly, we provided a wide characterization of the biological effects of the MB extract, a first step to establish a new phytotherapeutic agent. We also showed that its antioxidant capacity, besides not selective, could be responsible for the protective effects against gastrointestinal disorders observed in the traditional use of $\mathrm{MB}$ by Brazilian population.

\section{Conflict of interest statement}

The authors have declared no conflict of interest.

\section{Acknowledgments}

We are grateful to Heloísa Lizotti Cilião (Universidade Estadual de Londrina) for her technical assistance and Hellen Kuasne (A. C. Camargo Cancer Center) for her technical assistance with the gene expression analysis. Juliana Mara Serpeloni was sponsored by a fellowship from Fundação de Amparo à Pesquisa do Estado de São Paulo (FAPESP), Process no. 2012/01996-0. The entire project was also supported by FAPESP, Process no. 2009/52237-9.

\section{References}

Aranda, P.S., LaJoie, D.M., Jorcyk, C.L., 2012. Bleach gel: a simple agarose gel for analyzing RNA quality. Electrophoresis 33, 366-369.

Barcelos, G.R., Grotto, D., Angeli, J.P.F., Serpeloni, J.M., Rocha, B.A., Bastos, J.K., Barbosa, F., 2011. Evaluation of antigenotoxic effects of plant flavonoids quercetin and rutin on HepG2 cells. Phytother. Res. 25, 1381-1388.

Berndt, K., Campanile, C., Muff, R., Strehler, E., Born, W., Fuchs, B., 2013. Evaluation of quercetin as a potential drug in osteosarcoma treatment. Anticancer. Res. 33, 1297-1306.

Bernhard, D., Schwaiger, W., Crazzolara, R., Tinhofer, I., Kofler, R., Csordas, A., 2003. Enhanced MTT-reducing activity under growth inhibition by resveratrol in CEM-C7H2 lymphocytic leukemia cells. Cancer Lett. 195, 193-199.

Chen, W., Li, Y., Li, J., Han, O., Ye, L., Li, A., 2011. Myricetin affords protection against peroxynitrite-mediated DNA damage and hydroxyl radical formation. Food Chem. Toxicol. 49, 2439-2444.

Choi, J.A., Kim, J.Y. Lee, J.Y. Kang, C.M., Kwon, H.J., Yoo, Y.D., Kim, T.W., Lee, Y.S., Lee, S.J., 2001. Induction of cell cycle arrest and apoptosis in human breast cancer cells by quercetin. Int. J. Oncol. 19, 837-844.

Chua, A., Thomas, P., Wijesundera, C., Clifton, P., Fenech, M., 2014. Effect of docosahexaenoic acid and furan fatty acids on cytokinesis block micronucleus cytome assay biomarkers in astrocytoma cell lines under conditions of oxidative stress. Environ. Mol. Mutagen. 55, 573-590.

Ciliao, H.L., Ribeiro, D.L., Camargo-Godoy, R.B., Specian, A.F., Serpeloni, J.M., Colus, I. M., 2015. Cytotoxic and genotoxic effects of high concentrations of the immunosuppressive drugs cyclosporine and tacrolimus in MRC-5 cells. Exp. Toxicol. Pathol. 67, 179-187.

da Costa Lopes, L., Albano, F., Laranja, G.A.T., Alves, L.M., Silva, L.F.M., de Souza, G.P. Magalhaes Araujo, I., Nogueira-Neto, J.F., Felzenszwalb, I., Kovary, K., 2000. Toxicological evaluation by in vitro and in vivo assays of an aqueous extract prepared from Echinodorus macrophyllus leaves. Toxicol. Lett. 116, 189-198.

Fenech, M., 2006. Cytokinesis-block micronucleus assay evolves into a "cytome" assay of chromosomal instability, mitotic dysfunction and cell death. Mutat Res. 600, 58-66.

Fenech, M., 2007. Cytokinesis-block micronucleus cytome assay. Nat. Protoc. 2, $1084-1104$.

Fenech, M., Kirsch-Volders, M., Natarajan, A.T., Surralles, J., Crott, J.W., Parry, J., Norppa, H., Eastmond, D.A., Tucker, J.D., Thomas, P., 2011. Molecular mechanisms of micronucleus, nucleoplasmic bridge and nuclear bud formation in mammalian and human cells. Mutagenesis 26, 125-132.

Ferreira, A.C., Neto, J.C., da Silva, A.C., Kuster, R.M., Carvalho, D.P., 2006. Inhibition of thyroid peroxidase by Myrcia uniflora flavonoids. Chem. Res. Toxicol. 19 351-355.

Ferreira, E.A., Gris, E.F., Felipe, K.B., Correia, J.G., Cargnin-Ferreira, E., Pedrosa, R.C. 2010. Potent hepatoprotective effect in $\mathrm{CCl}(4)$-induced hepatic injury in mice of phloroacetophenone from Myrcia multiflora. Libyan. J. Med. 5, 4891-4900.

Ferreira, E.A., Gris, E.F., Rebello, J.M., Correia, J.F., de Oliveira, L.F., Pedrosa, R.C., 2011 The 2',4',6'-trihydroxyacetophenone isolated from Myrcia multiflora has antibesity and mixed hypolipidemic effects with the reduction of lipid intestinal absorption. Planta Med. 77, 1569-1574.

Haddad, A.O., Venkateswaran, V., Viswanathan, L., Teahan, S.J., Fleshner, N.E., Klotz, L.H., 2006. Novel antiproliferative flavonoids induce cell cycle arrest in human prostate cancer cell lines. Prostate Cancer Prostatic Dis. 9, 68-76.

Hammad, S., Marchan, R., Bolt, H.M., 2014. Research on plant extracts and phytochemicals: criteria for evaluation. Arch. Toxicol. 88, 11-13.

Hashimoto, G., 1996. Illustrated Encyclopedia of Brazilian Medicinal Plants. Abocsha, Japan, p. 601

Hayder, N., Bouhlel, I., Skandrani, I., Kadri, M., Steiman, R., Guiraud, P., Mariotte, A M., Ghedira, K., Dijoux-Franca, M.G., Chekir-Ghedira, L., 2008. In vitro antioxidant and antigenotoxic potentials of myricetin-3-o-galactoside and myricetin-3-o-rhamnoside from Myrtus communis: modulation of expression of genes involved in cell defence system using cDNA microarray. Toxicol. Vitr. 22, 567-581.

Heeba, G.H., Mahmoud, M.E., 2014. Dual effects of quercetin in doxorubicin-induced nephrotoxicity in rats and its modulation of the cytotoxic activity of doxorubicin on human carcinoma cells. Environ. Toxicol. . http://dx.doi.org/10.1002/ tox. 22075

Jeong, H.J., Koo, B.S., Kang, T.H., Shin, H.M., Jung, S., Jeon, S., 2015. Inhibitory effects of Saururus chinensis and its components on stomach cancer cells. Phytomedicine 22, 256-261.

Jirawatnotai, S., Hu, Y., Livingston, D.M., Sicinski, P., 2012. Proteomic identification of a direct role for cyclin d1 in DNA damage repair. Cancer Res, 72, 4289-4293.

Landrum, L., Kawasaki, M., 1997. The genera of Myrtaceae in Brazil: an illustrated synoptic treatment and identification keys. Brittonia 49, 508-536.

Leal, M.F., do Nascimento, J.L.M., da Silva, C.E.A., Lamarao, M.F.V., Calcagno, D.Q. Khayat, A.S., Assumpcao, P.P., Cabral, I.R., Smith, M.A.C., Burbano, R.R., 2009. Establishment and conventional cytogenetic characterization of three gastric cancer cell lines. Cancer Genet. Cytogenet. 195, 85-91.

Lee, K.W., Bode, A.M., Dong Z., 2011. Molecular targets of phytochemicals for cancer prevention. Nat. Rev. Cancer. 11, 211-218.

Li, Y., Duan, S., Jia, H., Bai, C., Zhang, L., Wang, Z., 2014. Flavonoids from tartary buckwheat induce G2/M cell cycle arrest and apoptosis in human hepatoma HepG2 cells. Acta Biochim. Biophys. Sin. 46, 460-470.

Matsuda, H., Nishida, N., Yoshikawa, M., 2002. Antidiabetic principles of natural medicines. V. aldose reductase inhibitors from Myrcia multiflora DC. (2): structures of myrciacitrins III, IV, and V. Chem. Pharm. Bull. 50, 429-431.

McGahon, A.J., Martin, S.J., Bissonnette, R.P., Mahboubi, A., Shi, Y., Mogil, R.J., Nishioka, W.K., Green, D.R., 1995. The end of the (cell) line: methods for the study of apoptosis in vitro. Methods Cell. Biol. 46, 153-185.

Mladenovic, M., Matic, S., Stanic, S., Solujic, S., Mihailovic, V., Stankovic, N., Katanic J., 2013. Combining molecular docking and 3-D pharmacophore generation to enclose the in vivo antigenotoxic activity of naturally occurring aromatic compounds: myricetin, quercetin, rutin, and rosmarinic acid. Biochem. Pharmacol. 86, 1376-1396.

Mosmann, T., 1983. Rapid colorimetric assay for cellular growth and survival: application to proliferation and cytotoxicity assays. J. Immunol. Methods 65, 55-63.

Myers, N., Mittermeier, R.A., Mittermeier, C.G., da Fonseca, G.A., Kent, J., 2000 Biodiversity hotspots for conservation priorities. Nature 403, 853-858.

Ock, C.Y., Kim, E.H., Choi, D.J., Lee, H.J., Hahm, K.B., Chung, M.H., 2012. 8-Hydroxydeoxyguanosine: not mere biomarker for oxidative stress, but remedy for oxidative stress-implicated gastrointestinal diseases. World J. Gastroenterol. 18 302-308.

Pepato, M.T., Oliveira, J.R., Kettelhut, I.C., Migliorini, R.H., 1993. Assessment of the antidiabetic activity of Myrcia uniflora extracts in streptozotocin diabetic rats. Diabetes Res. 22, 49-57.

Pfaffl, M.W., 2001. A new mathematical model for relative quantification in realtime RT-PCR. Nucl. Acids Res. 29, 2002-2007.

Pott, A., Pott, V.J., Souza, T.W., 2006. Plantas daninhas de pastagens na região de cerrados, pp. 15.

Repetto, G., Del Peso, A., Zurita, J.L., 2008. Neutral red uptake assay for the 
estimation of cell viability/cytotoxicity. Nat. Protoc. 3, 1125-1131.

Russo, E.M., Reichelt, A.A., De-Sa, J.R., Furlanetto, R.P., Moises, R.C., Kasamatsu, T.S., Chacra, A.R., 1989. Clinical trial of Myrcia uniflora and Bauhinia forficata leaf extracts in normal and diabetic patients. Braz. J. Med. Biol. Res. 23, 11-20.

Saldanha, L.L., Vilegas, W., Dokkedal, A.L., 2013. Characterization of flavonoids and phenolic acids in Myrcia bella Cambess. using FIA-ESI-IT-MS(n) and HPLC-PADESI-IT-MS combined with NMR. Molecules 18, 8402-8416.

Salvador, M.J., de Lourenco, C.C., Andreazza, N.L., Pascoal, A.C., Stefanello, M.E., 2011 Antioxidant capacity and phenolic content of four Myrtaceae plants of the south of Brazil. Nat. Prod. Commun. 6, 977-982.

Schwartz, G.K., Shah, M.A., 2005. Targeting the cell cycle: a new approach to cancer therapy. J. Clin. Oncol. 23, 9408-9421.

Seibert, H., Balls, M., Fentem, J.H., Bianchi, V., Clothier, R.H., Dierickx, P.J., Ekwall, B. Garle, M.J., Gómez-Lechón, M.J., Gribaldo, L., Güilden, M., Liebsch, M., Rasmussen, E., Roguet, R., Shrivastava, R., Walum, E., 1996. Acute toxicity testing in vitro and the classification and labelling of chemicals. ATLA 24, 499-510.

Sloczynska, K., Powroznik, B., Pekala, E., Waszkielewicz, A.M., 2014. Antimutagenic compounds and their possible mechanisms of action. J. Appl. Genet. 55 273-285.

Spruyt, M., Buquicchio, F., 1994. Gene Runner (v.3.01) for Windows. Available at: 〈http://www.generunner.net/〉 (accessed 12.09.15).

Sun, F., Zheng, X.Y., Ye, J., Wu, T.T., Wang, J., Chen, W., 2012. Potential anticance activity of myricetin in human T24 bladder cancer cells both in vitro and in vivo. Nutr. Cancer. 64, 599-606.
Suzuki, H., Nishizawa, T., Tsugawa, H., Mogami, S., Hibi, T., 2012. Roles of oxidative stress in stomach disorders. J. Clin. Biochem. Nutr. 50, 35-39.

Tai, J., Cheung, S.S.C., Ou, D., Warnock, G.L., Hasman, D., 2014. Antiproliferation activity of Devil's club (Oplopanax horridus) and anticancer agents on human pancreatic cancer multicellular spheroids. Phytomedicine 21, 506-514.

Vareda, P.M.P., Saldanha, L.L., Camaforte, N.A.P.D., Violato, N.M., Dokkedal, A.L., Bosqueiro, J.R., 2014. Myrcia bella Leaf extract presents hypoglycemic activity via PI3k/Akt insulin signaling pathway. Evid. Based Complement. Altern. Med., $1-10$.

Wang, H., Khor, T.O., Shu, L., Su, Z.Y., Fuentes, F., Lee, J.H., Kong, A.N., 2012. Plants vs. cancer: a review on natural phytochemicals in preventing and treating cancers and their druggability. Anticancer Agents Med. Chem. 12, 1281-1305.

Wang, W., VanAlstyne, P.C., Irons, K.A., Chen, S., Stewart, J.W., Birt, D.F., 2004. Individual and interactive effects of apigenin analogs on G2/M cell-cycle arrest in human colon carcinoma cell lines. Nutr. Cancer. 48, 106-114.

Xu, H., Yu, J., Sun, Y., Xu, X., Li, L., Xue, M., Du, G., 2013. Scutellaria barbata D. don extract synergizes the antitumor effects of low dose 5-fluorouracil through induction of apoptosis and metabolism. Phytomedicine 20, 897-903.

Zhang, Q., Zhao, X.H., Wang, Z.J., 2009. Cytotoxicity of flavones and flavonols to a human esophageal squamous cell carcinoma cell line (KYSE-510) by induction of G2/M arrest and apoptosis. Toxicol. Vitr. 23, 797-807.

Zhang, X.H., Zou, Z.Q., Xu, C.W., Shen, Y.Z., Li, D., 2011. Myricetin induces G2/M phase arrest in HepG2 cells by inhibiting the activity of the cyclin B/Cdc2 complex. Mol. Med. Rep. 4, 273-277. 